\title{
Dampak Pengembangan Pariwisata dan Sikap Nelayan di Desa Pangandaran
}

\section{Impact of Tourism Development and Fisherman Attitudes in Pangandaran Village}

\author{
Elbie Yudha Pratama ${ }^{1}$, Rilus A Kinseng ${ }^{1}$ \\ ${ }^{1}$ Departemen Sains Komunikasi dan Pengembangan Masyarakat, \\ Fakultas Ekologi Manusia (FEMA)-IPB
}

\begin{abstract}
Development of coastal tourism can give directly impact on the social and cultural life of fisherman communities and influence the attitudes of fishermen. This study intend to analyze the impact of tourism development on the social structure and cultural values as well as analyzing the attitudes of fishermen towards the tourism development. The research was conducted in Pangandaran village using survey methods. The results showed that the development of tourism impact on the social structure of fishermen namely the growth of social organization, social stratification, migration and composition of the population, as well as the livelihoods and incomes. Whereas the impact on the cultural value of fishermen include namely the waning tradition of local fishermen, fishermen lifestyle changes, and increased knowledge of fishermen. Fishermen status and income level have a real relationship with the attitude of fishermen, whereas age and education level did not have a real relationship with the attitude of fishermen.
\end{abstract}

Keywords: tourism development, impact towards social structure, impact towards cultural values, and fisherman attitudes

\begin{abstract}
Abstrak
Pengembangan pariwisata pesisir secara langsung dapat memberikan dampak pada kehidupan sosial budaya masyarakat nelayan serta menyebabkan terbentuknya sikap nelayan. Penelitian ini bertujuan untuk menganalisis dampak pengembangan pariwisata terhadap struktur sosial dan nilai budaya nelayan serta menganalisis sikap nelayan terhadap pengembangan pariwisata. Penelitian ini dilakukan di Desa Pangandaran dengan menggunakan metode survei. Hasil penelitian menunjukkan bahwa pengembangan pariwisata memberikan dampak pada struktur sosial nelayan yang meliputi tumbuhnya organisasi sosial, stratifikasi sosial, migrasi dan komposisi penduduk, serta mata pencaharian dan pendapatan. Sedangkan dampak pada nilai budaya nelayan meliputi memudarnya tradisi nelayan lokal, perubahan gaya hidup nelayan, dan bertambahnya pengetahuan nelayan. Status nelayan dan tingkat pendapatan memiliki hubungan nyata dengan sikap nelayan, sedangkan usia dan tingkat pendidikan tidak memiliki hubungan nyata dengan sikap nelayan.
\end{abstract}

Kata kunci: pengembangan pariwisata, dampak terhadap struktur sosial, dampak terhadap nilai budaya, dan sikap nelayan

\section{Pendahuluan}

Indonesia merupakan negara yang memiliki kekayaan sumberdaya alam dan lingkungan yang melimpah. Indonesia juga dikenal sebagai negara maritim dan merupakan negara kepulauan terbesar di dunia dengan luas laut 5,8 juta $\mathrm{km}^{2}$ dan jumlah pulau sekitar 17.504 buah yang dikelilingi oleh garis pantai sepanjang $81.290 \mathrm{~km}$. Letak Indonesia yang sangat strategis menjadikan Indonesia dikenal sebagai zamrud khatulistiwa yang memiliki pesona keanekaragaman alam dan budaya. Berbagai keistimewaan yang dimiliki tersebut menjadikan Indonesia memiliki berbagai potensi sumberdaya alam khususnya wilayah pesisir dalam rangka mengembangkan pariwisata terutama pariwisata alam. Potensi sumberdaya pesisir yang dimiliki Indonesia antara lain adalah keindahan terumbu karang yang ada di setiap perairan laut dangkal, hutan mangrove yang memiliki keanekaragaman hayati dan berbagai sumberdaya laut lainnya seperti ikan, mineral, dan bahan tambang yang bernilai tinggi. Potensi yang besar ini memberikan peluang yang cukup besar dalam perkembangan pariwisata karena dengan pengembangan pariwisata akan meningkatkan devisa negara.

Pengembangan bidang pariwisata tidak hanya ditujukan untuk meningkatkan devisa bagi negara, namun juga diharapkan dapat ikut berperan sebagai pendongkrak pembangunan di Indonesia. Adapun pengembangan pariwisata di Indonesia memiliki delapan keuntungan, yaitu meningkatkan kesempatan berusaha, meningkatkan kesempatan kerja bagi warga meningkatkan penerimaan pajak,

${ }^{1}$ Korespondensi penulis 
meningkatkan pendapatan nasional, mempercepat proses pemerataan pendapatan, meningkatkan nilai tambah produk hasil kebudayaan, memperluas pasar produk dalam negeri, dan memberikan dampak multiplier effect dalam perekonomian sebagai akibat pengeluaran wisatawan, para investor maupun perdagangan luar negeri (Bappenas, 2008).

Penelitin Retnowati (2004) menjelaskan bahwa bidang pariwisata juga berpotensi memicu terjadinya perubahan perilaku masyarakat, memudarnya nilai dan norma sosial, kehilangan identitas, dan juga konflik sosial, pergeseran mata pencaharian dan pencemaran lingkungan. Berbagai hal tersebut rentan terjadi di masyarakat sebagai akibat dari perkembangan pariwisata. Namun berbagai dampak negatif yang ditimbulkan dari perkembangan pariwisata dapat diantisipasi oleh masyarakat itu sendiri. Hal-hal tersebut tidak hanya terjadi pada pengembangan pariwisata di daerah persawahan, hutan, dan pegunungan akan tetapi dampak tersebut dapat terjadi di daerah pariwisata pesisir yang pada saat ini difokuskan untuk dijadikan daerah tujuan wisata oleh pemerintah daerah. Penetapan wilayah pesisir dijadikan sebagai daerah tujuan wisata tidak terlepas dari keindahan alam dan pesona laut yang dimiliki sebagian besar laut di Indonesia.

Perkembangan pariwisata di daerah pesisir secara langsung maupun tidak akan memberikan dampak. Perkembangan pariwisata di daerah pesisir secara langsung akan melibatkan masyarakat pesisir yang sebagian besar berprofesi sebagai nelayan. Karakteristik sosial yang dimiliki masyarakat nelayan berbeda dengan masyarakat lainnya secara umum. Hal tersebut disebabkan oleh perbedaan karakteristik sumberdaya yang dihadapi (Satria, 2002). Sejenak apabila kita perhatikan nelayan yang tinggal di daerah pedesaan di Indonesia memiliki banyak potensi untuk dijadikan objek pembangunan dalam berbagai sektor terutama dalam sektor pariwisata. Berbagai macam jenis pariwisata dapat dikembangkan di Indonesia, salah satunya adalah melalui program desa wisata.

Menurut penelitian Soemarno (2010), desa wisata biasanya merupakan kawasan pedesaan yang memiliki beberapa karakteristik khusus yang layak untuk dijadikan daerah tujuan wisata. Penetapan suatu daerah menjadi kawasan desa wisata tidak terlepas dari beberapa hal seperti ciri tradisi dan kebudayaan yang khas yang ditunjukkan dengan makanan khas daerah, hubungan sosial antar masyarakat, dan sistem pertanian yang menjadi ciri dari sebuah desa wisata.
Kondisi ekologis dan faktor sumberdaya alam yang masih terjaga kelestariannya juga merupakan salah satu faktor penetapan suatu daerah menjadi kawasan desa wisata.

Program Desa Wisata adalah suatu program yang bertujuan untuk meningkatkan kesejahteraan masyarakat khususnya bagi masyarakat miskin di pedesaan. Masyarakat miskin dapat ditemukan hampir di seluruh pedesaan di Indonesia, tidak terkecuali pada masyarakat nelayan. Mubyarto, Soetrisno, dan Dove (1994) mengatakan bahwa keluarga nelayan pada umumnya lebih miskin daripada keluarga petani atau pengrajin. Pengembangan program desa wisata diharapkan dapat mengatasi masalah-masalah umum di pedesaan khususnya masalah kemiskinan. Desa wisata juga diharapkan dapat meningkatkan kesejahteraan masyarakat nelayan dengan melibatkan masyarakat sebagai objek dalam pengembangan desa wisata dan juga diharapkan dapat meningkatkan kondisi ekonomi masyarakat dengan mengembangkan potensi alam.

Barlan (2013) mengungkapkan bahwa perubahan status desa menjadi desa wisata di Desa Pangandaran memberikan dampak positif dimana peluang lapangan pekerjaan meningkat dan akses terhadap sektor ekonomi kota juga semakin tinggi, namun ternyata hal ini tidak mampu sepenuhnya dimanfaatkan oleh masyarakat miskin yang ada di Desa Pangandaran. Desa Pangandaran merupakan salah satu Desa di Kecamatan Pangandaran, Kabupaten Ciamis yang pada saat ini telah difokuskan untuk dijadikan desa wisata. Posisi desa yang dekat dengan pantai menjadikan wilayah Pangandaran memiliki daya tarik wisata yang utama.Oleh karena itu hampir seluruh kegiatan wisata dilakukan di sepanjang kawasan pantai. Perkembangan wisata di Desa Pangandaran secara langsung telah memberikan dampak bagi kehidupan sosial, budaya dan ekonomi nelayan. Berdasarkan alasan tersebut, menarik untuk menganalisis dampak sosial, budaya dan menganalisis ekonomi nelayan Desa Pangandaran sebagai akibat dari perkembangan desa wisata.

\section{Metode Penelitian}

Pendekatan penelitian yang digunakan dalam penelitian ini adalah kombinasi metode kualitatif dan kuantitatif. Data kualitatif diperoleh melalui wawancara mendalam dan pengamatan langsung 
di lokasi penelitian untuk menggali pemahaman responden secara subjektif. Pendekatan kuantitatif yang digunakan adalah penelitian survey yaitu penelitian yang mengambil sampel dari satu populasi dan menggunakan kuesioner. Jenis data yang digunakan dalam penelitian ini adalah data primer dan data sekunder.

Responden dalam penelitian ialah sebanyak 50 orang nelayan. Pengambilan responden dengan menggunakan metode Stratified Random Sampling. Teknis analisis data yang dilakukan adalah analisis data kualitatif dan kuantitatif. Data kualitatif baik data primer maupun sekunder yang telah didapatkan akan diolah melalui tiga tahap kegiatan analisis data dan dilakukan secara bersamaan, yaitu reduksi data, penyajian data, dan penarikan kesimpulan (Sitorus, 1998). Analisis secara statistik dengan menggunakan uji Rank Spearman.

\section{Hasil dan Pembahasan}

Desa Pangandaran merupakan salah satu desa yang terletak di wilayah Kecamatan Pangandaran, Kabupaten Ciamis, Provinsi Jawa Barat. Desa Pangandaran merupakan wilayah pesisir di pantai selatan Jawa yang memiliki panjang pantai sepanjang $7 \mathrm{~km}$. Sebelah utara desa ini berbatasan langsung dengan Desa Babakan, sebelah selatan berbatasan dengan Samudera Hindia, sebelah barat berbatasan dengan Desa Pananjung dan sebelah timur berbatasan dengan wilayah Samudera Indonesia. Wilayah Desa Pangandaran terbagi menjadi 3 dusun, yaitu Dusun Pangandaran Barat, Dusun Pangandaran Timur, dan Dusun Parapat yang terbagi dalam 14 Rukun Warga dan 46 Rukun Tetangga.

Desa Pangandaran terdiri atas 46 RT yang tersebar dalam 3 dusun. Setiap dusun yang ada di Desa Pangandaran dihuni oleh penduduk lokal yang mayoritas berasal dari suku Sunda dan Jawa. Pendatang di Desa Pangandaran umumnya berasal dari daerah Jawa Tengah dan Sumatera Utara. Jumlah penduduk yang tinggal menetap di desa ini berjumlah 9.240 penduduk dengan proporsi 4.602 jumlah penduduk laki-laki dan 4.638 jumlah penduduk perempuan.

Sebagian besar wilayah Desa Pangandaran merupakan wilayah pesisir dimana mayoritas penduduknya bermata pencaharian sebagai nelayan. Jumlah nelayan yang ada sebanyak 1.874 jiwa. Dalam pembagiannya terdapat dua kategori nelayan yaitu nelayan pemilik (juragan) dan nelayan buruh (ABK) yang dikenal sebagai janggol pada masyarakat Desa Pangandaran. Nelayan juragan adalah nelayan yang memiliki perahu dan alat tangkap, nelayan juragan di Desa Pangandaran ada yang ikut melaut dan adapula yang hanya mengontrol dari darat. Nelayan buruh (ABK/Janggol) adalah nelayan yang tidak memiliki perahu dan alat tangkap, dan biasanya hanya mengeluarkan tenaga saja. Belakangan ini dikenal sistem pengelompokkan nelayan di Desa Pangandaran, sistem pengelompokkan tersebut berhubungan dengan kegiatan pariwisata yang ada di Desa Pangandaran. Berdasarkan sistem pengelompokkan tersebut nelayan terbagi menjadi nelayan pariwisata dan nelayan non pariwisata. Nelayan pariwisata adalah nelayan yang bekerja di bidang pariwisata seperti menyewakan perahu, menyewakan sarana olahraga air, dan biasanya mencari ikan untuk dikonsumsi sendiri. Sedangkan nelayan non-pariwisata adalah nelayan yang hanya bekerja mencari ikan di laut dan tidak bersentuhan dengan kegiatan pariwisata. Fokus pada penelitian ini adalah pada nelayan non pariwisata karena ingin melihat dampak yang diterima nelayan non-pariwisata akibat perkembangan pariwisata.

Selain objek wisata pantai, Pangandaran juga memiliki berbagai macam objek wisata lainnya seperti Cagar Alam, Event Wisata, dan Pusat Kuliner serta Cenderamata. Objek wisata Cagar Alam merupakan satu-satunya objek wisata hutan yang ada di Pangandaran, Kabupaten Ciamis. Selain itu terdapat juga Event Wisata yang diadakan sebagai upaya meningkatkan daya tarik wisatawan untuk berkunjung. Kegiatan yang ada di dalam Event Wisata antara lain adalah: (i) Pangandaran International Kite Festival, yang merupakan kegiatan festival layanglayang yang diadakan pada saat musim liburan sekolah yaitu sekitar bulan Juli-Agustus dan berlokasi di Pantai Timur dengan diikuti puluhan peserta dari dalam dan luar negeri; (ii) Hajat Laut atau syukuran nelayan. Kegiatan ini merupakan acara tradisi tahunan yang diadakan setiap malam jumat kliwon pada bulan Muharram yang diadakan oleh masyarakat lokal sebagai ungkapan rasa syukur kepada Tuhan Yang Maha Esa atas rezeki dan keselamatan hidup yang telah diberikan selama setahun. Acara pelepasan sesaji yang berupa kepala binatang dan penaburan bunga ke tengah laut menjadi daya tarik tersendiri bagi pengunjung yang datang untuk melihat.

Kegiatan pariwisata tidak hanya memerlukan 
Tabel 1 Jumlah dan Persentase Responden berdasarkan Sikap terhadap Perkembangan Pariwisata di Desa Pangandaran Tahun 2013

\begin{tabular}{lcc}
\hline \multicolumn{1}{c}{ Kategori Sikap } & Jumlah (orang) & Persentase (\%) \\
\hline Sangat Tidak & 0 & 0,00 \\
Setuju & 0 & 0,00 \\
Tidak Setuju & 3 & 6,00 \\
Setuju & 23 & 46,00 \\
Sangat Setuju & 24 & 48,00 \\
\hline Total & 50 & 100,00
\end{tabular}

objekpariwisatasaja,namun diperlukanjuga pengguna (subjek pariwisata) untuk menunjang keberlanjutan pariwisata di suatu daerah. Subjek pariwisata yang dimaksud adalah para pelaku usaha yang berfungsi sebagai penyedia jasa yang dibutuhkan oleh para wisatawan. Semakin berkembangnya pariwisata di Desa pangandaran membuat semakin bertambahnya jumlah wisatawan yang datang. Wisatawan yang datang tidak hanya wisawatan lokal bahkan tidak sedikit wisatawan mancanegara dari berbagai negara juga datang ke Pangandaran.

Keberadaan wisatawan di Desa Pangandaran jelas membutuhkan suatu jasa yang dapat menyediakan segala kebutuhan yang diperlukan selama berada disana. Keadaan tersebut yang kemudian melatarbelakangi tumbuhnya organisasi-organisasi sosial yang mampu menyediakan kebutuhan wisatawan dalam bidang jasa.

Organisasi yang ada merupakan organisasi formal berbadan hukum yang memiliki AD/ART dalam pelaksanaannya. Organisasi yang terbentuk sejak berkembangnya pariwisata tersebut bernama Organisasi Perahu Pesiar Pangandaran (OP3) yang didirikan pada tanggal 4 November 2009. Organisasi tersebut bersifat sosial kemasyarakatan yang didirikan dengan tujuan untuk memberdayakan masyarakat dan menumbuhkembangkan potensi masyarakat. Dalam pelaksanaannya organisasi tersebut mengadakan hubungan dan kerjasama dengan instansi pemerintah, swasta, dan badan-badan lainnya guna mendukung kelancaran dalam mencapai maksud dan tujuan organisasi. OP3 memiliki keanggotaan yang bergerak di bidangnya masing-masing yaitu kelompok binaan budidaya perikanan, kelompok binaan dalam bidang lingkungan hidup wisata bahari, dan kelompok binaan bidang pariwisata.

Berkembangnya pariwisata tidak membuat jumlah nelayan juragan menjadi semakin meningkat, sebaliknya dengan berkembangnya sektor pariwisata membuat banyak penduduk dari luar datang ke Pangandaran untuk merasakan dampak dari kegiatan pariwisata. Akan tetapi penduduk yang datang tersebut tidak memiliki cukup modal dan pengetahuan untuk menjadi nelayan juragan dan mereka hanya mampu menjadi buruh yang membuat jumlah nelayan buruh terus mengalami peningkatan. Oleh karena itu perkembangan pariwisata tidak sepenuhnya membawa perubahan pada stratifikasi sosial dalam masyarakat nelayan.

Cohen (1984) menyebutkan bahwa salah satu dampak sosial pariwisata adalah migrasi penduduk dari dan ke daerah pariwisata. Perkembangan pariwisata di Desa Pangandaran secara langsung menyebabkan kepadatan penduduk di daerah tersebut semakin bertambah. Hal tersebut disebabkan karena Pangandaran sebagai daerah tujuan wisata dapat dijadikan sebagai tempat mendapatkan penghasilan. Awalnya sebelum sektor pariwisata belum mengalami perkembangan pesat, hanya penduduk Pangandaran asli yang bekerja dan membuka usaha. Mereka umumnya membuka warung yang menjual makanan kecil, minuman, membuka kios pakaian, cendera mata, dan sebagainya.

Semakin berkembangnya pariwisata di Desa pangandaran menyebabkan penduduk yang berasal dari luar Pangandaran yang bermigrasi ke Pangandaran. Penduduk yang datang pada umumnya berasal dari daerah di sekitar Pangandaran seperti, Ciamis, Garut, Tasikmalaya, Cilacap dan bahkan ada yang berasal dari Pulau Sumatera khususnya Medan. Kedatangan penduduk dari luar tidak lain adalah untuk mencarilahan pekerjaan di Desa Pangandaran yang menyebabkan terjadinya perubahan pada komposisi penduduk. Hal 
Tabel 2 Nilai Signifikansi antara Karakteristik Individu dengan Sikap Nelayan terhadap Perkembangan Pariwisata

\begin{tabular}{lcc}
\hline Variabel pengaruh & Variabel terpengaruh & Signifikansi \\
\hline Usia & Sikap & 0,351 \\
Status Nelayan & Sikap & $0,015^{*}$ \\
Tingkat pendidikan & Sikap & 0,880 \\
Tingkat pendapatan & Sikap & $0,024^{*}$ \\
\hline
\end{tabular}

Keterangan : *Berhubungan nyata pada $\mathrm{p}<0,05$

tersebut sejalan dengan teori dari Harper (1989) yang mengatakan bahwa perubahan pada personal, dalam arti jumlah dan komposisi manusia yang dijelaskan dengan penduduk yang memiliki pengalaman hidup berbeda masuk dan keluar dari suatu struktur sosial tidak membawa perubahan berarti pada struktur sosial.

Qomaruddin (2012) dalam penelitiannya menjelaskan bahwa sebelum dikembangkan menjadi kawasan wisata, masyarakat Karimun Jawa umumnya bermatapencaharian sebagainelayan, akan tetapiseiring berjalannya perkembangan pariwisata di Karimun Jawa masyarakat beralih mata pencaharian kedalam bidang jasa yang menunjang kegiatan pariwisata antara lain membuat penginapan, menyediakan penyewaan kapal dan alat menyelam, dan sebagian masih berhubungan dengan perikanan seperti menjual ikan asin dan ikan bakar.

Masyarakat Pangandaran pada awalnya menggantungkan hidupnya dari hasil melaut. Menangkap ikan merupakan satu-satunya pekerjaan yang dapat dilakukan oleh sebagian besar masyarakat Desa Pangandaran yang berprofesi sebagai nelayan. Pendapatan yang diperoleh hanya berasal dari hasil melaut yang digunakan untuk memenuhi kebutuhan hidup keluarganya. Penghasilan nelayan pada saat itu dapat dikatakan pas-pasan karena hanya dapat digunakan untuk memenuhi kebutuhan sandang, pangan, dan papan.

Berkembangnya pariwisata di Pangandaran memberikan dampak yang positif bagi masyarakat lokal. Pariwisata diyakini oleh masyarakat dapat memberikan perubahan ke arah yang lebih baik. Penyerapan tenaga kerja akibat perkembangan pariwisata di Desa Pangandaran selalu bertambah hampir di setiap sektor pekerjaan. Manfaat positif tersebut tidak hanya dirasakan oleh nelayan juragan saja tetapi juga dirasakan oleh nelayan buruh meskipun tidak seluruh nelayan buruh mampu bersaing dan terlibat dalam sektor pariwisata.

Perkembangan pariwisata memberikan manfaat tersendiri bagi nelayan Pangandaran, selain dapat menciptakan mata pencaharian baru bagi nelayan juga dapat meningkatkan harga penjualan dari hasil tangkapan. Wisatawan pada umumnya mulai ramai berdatangan pada saat libur akhir pekan, dimana permintaan atas ikan dan udang meningkat. Meningkatnya permintaan atas ikan dan udang membuat harga ikan dan udang melambung. Hal tersebut dapat memberikan manfaat bagi nelayan yang dapat meningkatkan hasil tangkapannya. Kondisi tersebut tidak hanya terjadi pada libur akhir pekan, pada saat libur hari raya, libur sekolah, dan libur nasional jumlah wisatawan yang berkunjung meningkat dua kali lipat dari hari libur akhir pekan. Kondisi tersebut sudah jelas akan memberikan keuntungan bagi nelayan. Banyak para wisatawan yang dari jauh hari sudah memesan ikan dan udang untuk dikonsumsi. Hal tersebut dilakukan karena biasanya pada musim liburan ikan, udang, dan makanan laut lainnya akan lebih cepat habis dikonsumsi oleh pengunjung yang datang. Harga ikan pada hari-hari biasanya dihargai Rp 40.000,00 untuk dua ekor, tetapi jika musim ramai wisatawan harganya bisa mencapai Rp 120.000,00.

Perkembangan pariwisata selain memberikan pengaruh pada kehidupan sosial masyarakat juga memberikan pengaruh pada nilai-nilai budaya yang dianut oleh masyarakat. Perubahan pada nilai-nilai budaya masyarakat tidak terlepas dari tuntutan lingkungan sekitar masyarakat. Pariwisata yang sudah mengalami perkembangan cukup lama secara tidak langsung menyebabkan semakin memudarnya tradisi masyarakat lokal.

Salah satu tradisi masyarakat lokal yang dianut sejak dahulu adalah larangan melaut pada harihari tertentu. Hari-hari yang diyakini sakral untuk pergi melaut adalah setiap malam selasa dan malam 
jumat termasuk pada malam Kliwon pada kedua hari tersebut. Masyarakat Pangandaran pada zaman dahulu selalu meyakini dan memegang teguh kepercayaan dari nenek moyang mereka bahwa setiap malam selasa dan malam jumat dilarang untuk pergi melaut dan apabila ada yang melanggar maka akan celaka. Larangan dari nenek moyang untuk pergi melaut tersebut bukan tanpa alasan untuk dipatuhi dan ditaati oleh para nelayan. Larangan tersebut memberikan makna tersendiri bahwa hari-hari tersebut dapat digunakan oleh nelayan untuk beri'tirakat di masjid, beribadah dan di sisi lain memberikan waktu bagi ikan untuk dapat berenang bebas dan beristirahat. Tradisi tersebut lama kelamaan menjadi semakin memudar dengan diikuti berbagai proses.

Awalnya nelayan banyak yang masih mentaati larangan untuk melaut pada malam selasa dan malam jumat termasuk pada malam kliwon, kemudian sebagian nelayan meninggalkan larangan untuk pergi melaut pada malam selasa dengan pergi melaut pada setiap malam selasa kecuali pada malam selasa Kliwon. Larangan melaut setiap malam selasa Kliwon kemudian ditinggalkan secara perlahan oleh nelayan Pangandaran, mereka tetap pergi melaut pada setiap malam selasa termasuk malam selasa kliwon. Semakin berkembangnya pariwisata memaksa nelayan untuk meningkatkan hasil tangkapannya karena akan memberikan keuntungan ekonomis kepada nelayan. Hal tersebut membuat nelayan Pangandaran menjadi semakin meninggalkan tradisi-tradisi yang sudah diyakini sejak lama oleh para leluhur. Ancaman celaka apabila tidak mentaati larangan tersebut kini tidak dihiraukan lagi oleh para nelayan. Larangan untuk pergi melaut pada setiap malam jumat termasuk malam jumat kliwon juga sudah perlahan-lahan ditinggalkan oleh para nelayan.

Pengembangan pariwisata juga memberikan dampak pada gaya hidup nelayan. Gaya hidup atau kebiasaan hidup merupakan perilaku seseorang yang ditunjukkan dalam aktivitas khususnya yang berkaitan dengan citra diri untuk dapat merefleksikan status sosialnya. Pariwisata di Pangandaran telah menyebabkan berubahnya gaya hidup dari sebagian besar nelayan lokal terutama nelayan yang berprofesi sebagai nelayan juragan. Perubahan tersebut ditandai oleh berbagai hal seperti, berubahnya tata cara berkelakuan, berubahnya pola hidup masyarakat yang diikuti dengan berubahnya status sosial masyarakat dan lain sebagainya. Perubahan gaya hidup pada masyarakat nelayan yang terjadi antara lain adalah meninggalkan kebiasaan bersilaturahmi karena sudah digantikan dengan handphone, cara berpakaian, dan bangunan rumah.

Masyarakat nelayan sudah banyak yang berkomunikasi dengan menggunakan alat komunikasi. Tata cara komunikasi langsung tatap muka berubah menjadi menggunakan alat komunikasi seperti telepon genggam. Hampir setiap nelayan memiliki telepon genggam yang dapat digunakan untuk berkomunikasi dengan rekan-rekannya. Hal tersebut telah menghilangkan kebiasaan untuk bersilaturahmi dengan teman, saudara, dan tetangga karena kebiasaan tersebut telah hilang dan digantikan oleh perkembangan teknologi.

Cara berpakaian masyarakat juga lambat laun mulai mengalami perubahan. Perubahan cara berpakaian tersebut sebagian besar karena dipengaruhi oleh cara berpakaian wisatawan asing yang ada di Pangandaran. Wisatawan asing yang datang dianggap sebagai panutan dan dijadikan contoh bagi masyarakat nelayan khususnya anak-anak nelayan. Anak-anak nelayan kemudian mengikuti cara berpakaian yang dianggap tidak senonoh. Sebagai sebuah desa yang islami perilaku tersebut kemudian mendapat teguran dari tokoh agama yang ada di Desa pangandaran. Teguran tersebut tidak hanya ditujukan bagi anakanak nelayan yang melakukan penyimpangan, tetapi juga ditujukan kepada wisatawan asing yang membawa perilaku 'barat' ke Pangandaran.

Perubahan gaya hidup yang lain juga ditunjukkan dari bentuk bangunan rumah nelayan. Perkembangan pariwisata membuat nelayan untuk merenovasi rumahnya sehingga terlihat lebih mewah dan juga dapat memberikan kenyamanan bagi para wisatawan untuk beristirahat. Hampir di setiap rumah nelayan sudah menggunakan keramik, tersedia televisi, dan air panas di setiap kamar mandinya. Hal ini disebabkan karena perkembangan pariwisata yang menuntut para nelayan untuk bergaya hidup seperti kebanyakan orang -orang di perkotaan. Perubahan gaya hidup tersebut hanya terjadi pada sebagian nelayan saja yang memiliki modal cukup untuk merenovasi rumahnya yang pada umumnya adalah nelayan juragan, tetapi ada juga sebagian kecil nelayan buruh yang dapat merenovasi rumahnya meskipun tidak semua nelayan buruh mampu melakukannya.

Keberadaan sektor pariwisata di Pangandaran 
menyebabkan semakin bertambahnya pengetahuan dan wawasan yang dimiliki oleh nelayan. Interaksi dengan wisatawan secara tidak langsung telah menyebabkan bertambahnya pengetahuan nelayan mengenai informasiinformasi dari luar. Keberadaan homestay yang pada umumnya disediakan oleh nelayan membuat nelayan tidak dapat terlepas dari interaksi dengan wisatawan ketika musim liburan. Wisatawan yang datang pun tidak jarang memberikan masukan-masukan tentang bagaimana cara menggunakan alat tangkap yang cocok baik, ramah lingkungan, dan tidak menganggu ekosistem yang lainnya.

\section{Sikap Nelayan terhadap Perkembangan Pariwisata}

Sikap terhadap perkembangan pariwisata adalah penilaian positif atau negatif yang diberikan oleh nelayan terhadap perkembangan pariwisata. Berdasarkan penilaian dari pernyataan yang diberikan, skor terendah dimiliki oleh responden (nelayan) yang menunjukkan sikap tidak setuju terhadap perkembangan pariwisata, sedangkan skor tertinggi dimiliki oleh responden yang menunjukkan sikap sangat setuju terhadap perkembangan pariwisata.

Sikap responden terhadap perkembangan pariwisata yang terjadi di Desa Pangandaran. Dari total responden, sebanyak 24 orang responden (48\%) menyatakan sikap sangat setuju terhadap perkembangan pariwisata, kemudian sebanyak 23 orang responden (46\%) menyatakan sikap setuju terhadap perkembangan pariwisata, lalu sebanyak 3 orang responden (6\%) menyatakan sikap tidak setuju terhadap pengembangan pariwisata, dan tidak ada responden yang memiliki sikap sangat tidak setuju terhadap pengembangan pariwisata yang terjadi di Desa Pangandaran. Hal tersebut menunjukkan bahwa perkembangan pariwisata di Desa Pangandaran cenderung disikapi positif oleh sebagian besar responden, namun terdapat 3 orang responden yang menyatakan sikap tidak setuju terhadap perkembangan pariwisata karena dirasakan tidak terlalu memberikan pengaruh pada kehidupan mereka.

\section{Hubungan Antara Karakteristik Individu dengan Sikap terhadap Perkembangan Pariwisata}

Pada penelitian ini karakteristik individu yang diuji adalah usia, status nelayan, tingkat pendidikan, dan juga tingkat pendapatan. Setiap karakteristik dari individu yang diuji dihubungkan dengan sikap nelayan terhadap perkembangan pariwisata di Desa Pangandaran. Karakteristik tersebut diuji melalui uji korelasi Rank Spearman untuk dapat mengetahui ada atau tidaknya hubungan dengan sikap nelayan terhadap perkembangan pariwisata. Uji korelasi Rank Spearman digunakan untuk melihat hubungan antara karakteristik individu yang meliputi usia, stratifikasi nelayan, tingkat pendidikan, dan tingkat pendapatan dengan sikap terhadap perkembangan pariwisata.

Status dari para nelayan memiliki hubungan yang nyata dengan sikap merka terhadap perkembangan pariwisata. Semakin tinggi status nelayan maka akan semakin positif sikap nelayan terhadap perkembangan pariwisata. Sebaliknya semakin rendah status nelayan maka akan semakin negatif pula sikapnya terhadap perkembangan pariwisata. Selanjutnya hubungan nyata juga ditunjukkan oleh variabel tingkat pendapatan dengan sikap. Tingkat pendapatan nelayan yang meningkat karena penjualan ikan yang meningkat pada sikap nelayan terhadap perkembangan pariwisata.

\section{Kesimpulan}

Perkembangan pariwisata di Desa Pangandaran memberikan dampak terhadap struktur sosial nelayan Desa Pangandaran. Dampak tersebut antara lain adalah munculnya organisasi-organisasi sosial yang terbentuk guna menyediakan kebutuhan jasa bagi para wisatawan yang melahirkan organisasi nelayan baru yaitu nelayan pariwisata, perubahan pada stratifikasi sosial nelayan yang ditunjukkan dengan perubahan dari nelayan buruh menjadi nelayan juragan, migrasi dan komposisi penduduk ke Desa Pangandaran semakin meningkat dan beragam yang didasari adanya kegiatan pariwisata di Desa Pangandaran, dan meningkatnya pendapatan nelayan dan penduduk lokal, serta terbukanya peluang usaha dan lapangan kerja. Perkembangan pariwisata di Desa Pangandaran memberikan dampak terhadap nilai-nilai budaya nelayan Desa Pangandaran. Dampak tersebut antara lain adalah memudarnya nilai-nilai budaya yang dianut oleh nelayan lokal seperti melanggar larangan melaut pada hari-hari tertentu, meningkatnya pola pikir ke arah komersialisme akibat pesatnya perkembangan pariwisata, berubahnya gaya hidup nelayan lokal akibat perkembangan pariwisata, dan bertambahnya wawasan nelayan lokal. Hasil uji statistik menunjukkan 
bahwa sekitar 90\% nelayan memiliki sikap setuju terhadap pengembangan pariwisata, khususnya yang mendapatkan manfaat ekonomis secara langsung dari adanya pariwisata, dan sisanya memiliki sikap tidak setuju terhadap pengembangan pariwisata karena tidak mampu untuk bersentuhan secara langsung dengan kegiatan pariwisata. Hasil pengolahan data penelitian menunjukkan bahwa status nelayan dan tingkat pendapatan memiliki hubungan nyata dengan sikap terhadap perkembangan pariwisata. Sedangkan usia dan tingkat pendidikan tidak memiliki hubungan nyata dengan sikap nelayan terhadap perkembangan pariwisata.

\section{Daftar Pustaka}

Acheson J. 1981. Anthropology of fishing. Annual review of anthropology. Vol. 10 (1981).

Barlan ZA. 2013. Desa wisata dan dampaknya terhadap terpinggirnya masyarakat nelayan, Studi kasus : masyarakat nelayan miskin Desa Pangandaran, Kecamatan Pangandaran, Kabupaten Ciamis Jawa Barat. Makalah hasil observasi.

Bappenas [Badan Perencanaan Pembangunan Nasional]. 2008. Dampak pariwisata terhadap perekonomian nasional. [internet]. [dikutip 10 Februari 2013]. Dapat diunduh dari : http:// kppo.bappenas.go.id/preview/282/

Cohen E. 1974. Who is a tourist? A conceptual clarification. Sociological Review.

1984. The sociology of tourism: approaches, issues, and finding annal of tourism research

Harper CL 1989. Exploring social change. New Jersey : Prentice-Hall

Imron M. 2003. Kemiskinan dalam masyarakat nelayan dalam Jurnal masyarakat dan budaya. Jakarta: PMB - LIPI.

Kinseng RA. 2011. Konflik kelas nelayan di Indonesia : Tinjauan kasus Balikpapan. Bogor: IPB Press

Marpaung H. 2002. Pengetahuan Kepariwisataan. Bandung: Alfabeta.

Mathieson A, Wall G. 1990. Tourism, Economic, Physical and Social Impact.

Mulyadi. 2007. Ekonomi kelautan. Jakarta: PT. Raja Grafindo Persada.

Notoatmodjo S. 2003. Pendidikan dan perilaku kesehatan. Jakarta: Rineka Cipta.

Pertiwi HD. 2011. Dampak keberadaan perusahaan pertambangan terhadap ekologi, sosial, dan ekonomi masyarakat di era otonomi daerah (kasus : Kelurahan Sampaja Utara, Kecamatan Samarinda Utara, Kota Samarinda). [skripsi]. Bogor: Institut Pertanian Bogor.

Qomaruddin. 2012. Perubahan sosial dan peran serta masyarakat dalam pengembangan kawasan wisata kepulauan Karimun Jawa. Makalah hasil observasi

Sedarmayanti. 2005. Membangun kebudayaan dan pariwisata. Bandung: Mandar Maju.

Soemarno. 2010. Desa wisata (Bahan ajar Universitas Brawijaya). http://marno.lecture.ub.ac.id/ files/2012/01/Desa-wisata.doc Diunduh pada tanggal 28 Januari 2013 pukul 15.00 WIB.

Sumarti dan Saharudin. 2001. Model kelembagaan ekonomi lokal untuk pemberdayaan masyarakat nelayan dalam pengelolaan pertanian kawasan pesisir dan pedesaan nelayan. Bogor: Laporan hasil penelitian hibah bersaing perguruan tinggi.

Widodo J, Suadi. 2008. Pengelolaan sumberdaya perikanan laut. Yogyakarta: Gajah Mada University Press.

Winarni S. 2001. Hubungan karakteristik sosial ekonomi petani dengan pemilihan ragam metode penyuluhan. Surakarta: Sebelas Maret

University Press.

Yoeti OA. 1996. Pengantar ilmu pariwisata. Bandung: Angkasa.

2008. Ekonomi pariwisata. introduksi, informasi, dan implementasi. Jakarta: Kompas

Yulianda F. 2007. Ekowisata bahari sebagai alternatif pemanfaatan sumberdaya pesisir berbasis konservasi. Disampaikan pada seminar sains 21 Februari 2007 pada Departemen Manajemen Sumberdaya Perairan, FPIK. IPB. 